\title{
Mapping and modeling eelgrass Zostera marina distribution in the western Baltic Sea
}

\author{
Philipp R. Schubert ${ }^{1, *}$, Wolfgang Hukriede ${ }^{1}$, Rolf Karez $^{2}$, Thorsten B. H. Reusch ${ }^{1}$ \\ ${ }^{1}$ Evolutionary Ecology of Marine Fishes, GEOMAR Helmholtz Center for Ocean Research Kiel, Düsternbrooker Weg 20, \\ 24105 Kiel, Germany \\ ${ }^{2}$ State Agency for Agriculture, Environment and Rural Areas Schleswig-Holstein (LLUR), Hamburger Chaussee 25,
} 24220 Flintbek, Germany

\begin{abstract}
In the northern hemisphere, eelgrass Zostera marina L. is the most important and widespread seagrass species. Despite its ecological importance, baseline data on eelgrass distribution and abundance are mostly absent, particularly in subtidal areas with relatively turbid waters. Here, we report a combined approach of vegetation mapping in the Baltic Sea coupled to a species distribution model (SDM). Eelgrass cover was mapped continuously in the summers of 2010 and 2011 with an underwater towed camera along $\sim 400 \mathrm{~km}$ of seafloor. Eelgrass populated $80 \%$ of the study region and occurred at water depths between 0.6 and $7.6 \mathrm{~m}$ at sheltered to moderately exposed coasts. Mean patch length was $128.6 \mathrm{~m}$ but was higher at sheltered locations, with a maximum of $>2000 \mathrm{~m}$. The video observations $(\mathrm{n}=7824)$ were used as empiric input to the SDMs. Using generalized additive models, 3 predictor variables (depth, wave exposure, and slope), which were selected based on Akaike's information criterion, were sufficient to predict eelgrass presence/absence. Along with a very good overall discriminative ability (area under the receiver-operating characteristic curve ROC/AUC $=0.82$ ), depth (as a proxy for light), wave exposure, and slope contributed 66,29 , and $5 \%$, respectively, to the final model. The estimated total areal extent of eelgrass in the study region amounts to $140.5 \mathrm{~km}^{2}$ and comprises about $11.5 \%$ of all known Baltic seagrass beds. The present work is, to the best of our knowledge, the largest study undertaken to date on vegetation mapping and the first to assess distribution of eelgrass quantitatively in the western Baltic Sea.
\end{abstract}

KEY WORDS: Species distribution - GAM - Habitat mapping $\cdot$ Habitat modeling $\cdot$ Depth limit . Patchiness

\section{INTRODUCTION}

Seagrass meadows are among the most productive and valuable ecosystems on Earth (Costanza et al. 1997). They act as ecological engineers (sensu Wright \& Jones 2006) and provide a multitude of important ecological services (Hemminga \& Duarte 2000, Larkum et al. 2006). At the same time, seagrass meadows are threatened worldwide by eutrophication, overfishing, coastal development, diseases, invasive species, and climate change (Reusch et al. 2005, Orth et al. 2006, Williams 2007, Moksnes et al.
2008, Waycott et al. 2009, Bockelmann et al. 2013). The areal extent of seagrass populations around the globe was recently estimated to decline at a rate of about $1.5 \% \mathrm{yr}^{-1}$, summing up to a total loss of seagrass area of at least $3370 \mathrm{~km}^{2}$ between 1879 and 2006 , representing $29 \%$ of the maximum area measured ever (Waycott et al. 2009). This loss rate is higher than for most other threatened ecosystems. Additionally, the rate of decline in seagrass meadows has accelerated over the past 8 decades from $<1 \% \mathrm{yr}^{-1}$ before 1940 to $5 \% \mathrm{yr}^{-1}$ after 1980 (Waycott et al. 2009). Locally, the observed global loss of sea- 
grass could be masked by the great variability of seagrass distribution (Frederiksen et al. 2004, van Tussenbroek et al. 2014) or even recovery of seagrass populations in some areas following release from stressors (e.g. Vaudrey et al. 2010).

In the Baltic Sea, the largest brackish water body of the world's oceans, sublittoral eelgrass Zostera marina L. meadows are one of the most important and extensive coastal ecosystems, covering at least $1227 \mathrm{~km}^{2}$ from the Kattegat through to the northeastern Baltic Sea (Boström et al. 2014). Eelgrass beds play an important role in coastal protection, help to remove excess nutrients, and provide food and nursery grounds for economically important fish species like cod, herring, eel, and plaice (e.g. Touchette \& Burkholder 2000, Beck et al. 2001, Christianen et al. 2013). Local studies indicate that eelgrass may cover large areas in shallow waters $(<10 \mathrm{~m})$ along the German coast (HELCOM 1998, Schubert et al. 2013, Boström et al. 2014). Yet, despite its presumed ecological importance for the coastal ecosystem in German waters, baseline data on eelgrass distribution, abundance, and spatial structure are virtually absent.

To assess the importance and function of eelgrass beds in the western Baltic Sea, baseline data on abundance, distribution, and spatial structure are urgently needed (Boström et al. 2002). Abundance and areal extent data of eelgrass are the foundation for any sensible calculations on production, nutrient cycling, carbon sequestration, importance for fish stocks, sediment transports, and other ecosystem services. Structure or spatial patterns of seagrass meadows can affect benthic community composition and ecosystem responses on varying scales from meters to hundreds of kilometers (Robbins \& Bell 1994, Turner et al. 1999). And while concepts of landscape ecology become more widely used in seagrass research (Boström et al. 2006 and references therein), baseline data of seagrass landscapes like patchiness or fragmentation are still missing.

Distribution maps on the basis of georeferenced presence/absence data are needed for managing as well as monitoring purposes, as eelgrass areal extent, health status, and depth limits are important indicators to assess the environmental status for several international directives or conventions, viz. HELCOM, the European Union (EU) Water Framework Directive (WFD), and the EU Marine Strategy Framework Directive (MSFD 2008, HELCOM 2009, Backer et al. 2010). Data on eelgrass distribution are also needed to assess the monetary value of ecosystem services provided by eelgrass habitats (Baden et al. 2003, Rönnbäck et al. 2007, Mangi et al. 2011). In addition, these data are prerequisites for managers and local communities for the preservation and protection of local ecosystem functioning in the course of planning and maintaining coastal infrastructure (e.g. harbors, piers, coastal protection, dredging of waterways).

One possible reason for the lack of studies concerning the distribution and abundance of eelgrass in the Baltic Sea could be that large-scale mapping of sublittoral vegetation in visually deep waters (deeper than vertical visibility, prohibiting remote sensing from aerial photography or satellite imagery) is costly and time-consuming and, in contrast to remote sensing, does not yield the areal extent of submerged vegetation directly. Thus, depending on mapping design and method (e.g. SCUBA, drop camera, towed camera), in turbid waters, only transect or point data are generated, which leave out large non-surveyed areas. To minimize costs of laborious mapping methodologies and to extrapolate statistical relationships from sampled to non-surveyed areas, species distribution modeling (SDM) of seagrass occurrence in relation to geophysical factors has recently been applied as a complementary approach (Bekkby et al. 2008, Grech \& Coles 2010, Downie et al. 2013, March et al. 2013a). Particularly at larger scales (>50 km), distribution modeling has contributed to a better understanding of the geophysical factors and processes structuring the distribution of seagrasses. Additionally, SDM allows scientists (1) to identify the potential distribution range of eelgrass under possibly changing conditions (e.g. light limitation due to eutrophication) and (2) to estimate past changes in eelgrass distribution via falsely predicted absences or presences. SDM is particularly useful in species that are common and widely distributed, have a relatively stable distribution, and are not extending their range (Guisan \& Thuiller 2005). These criteria apply to eelgrass in the western Baltic Sea.

The present work combines the largest and most thorough study undertaken to date on vegetation mapping in the Baltic Sea - accomplished by towing an underwater camera system along transects of about $400 \mathrm{~km}$ length - with a subsequent SDM and GIS analysis, which identifies geophysical factors that influence eelgrass occurrence and allows extrapolation into non-surveyed areas. More specifically, the main objectives of our study were to explore eelgrass distribution along the northern German Baltic Sea coast and to locate present depth limits (shallow and deep) of the meadows. Additionally, the mapping should help to reveal the population's spatial structure concerning cover and patchiness. With the 
model, we tried to estimate the areal extent of eelgrass populations in the study region and the influence of a range of geophysical factors on eelgrass distribution. Finally, for possible restoration projects, we tried to locate sites where eelgrass is missing despite suitable conditions for growth.

\section{METHODS}

\section{Study region}

The study region is situated in the Baltic Sea, the largest brackish water basin in the world, which is characterized by steep physical and chemical gradients, limited water exchange, low biodiversity, and strong anthropogenic impacts (Elmgren 2001). Eelgrass was mapped and modeled along the coastline of Schleswig-Holstein, between Denmark in the north and the German federal state of Mecklenburg-Western Pomerania in the southeast (total sea area ca.
$3680 \mathrm{~km}^{2}$, Fig. 1). The outer coastline of SchleswigHolstein has a length of $397 \mathrm{~km}$ (including the island of Fehmarn, not including the Schlei Fjord). Water depths in the shallow western Baltic Sea range from 0 to $40 \mathrm{~m}$, but we restricted our field study to the extent of the potentially habitable depth zone for eelgrass today ( 0 to $10 \mathrm{~m}$ depth). The total area of this depth zone in the study area is ca. $588 \mathrm{~km}^{2}$ (not including the Schlei Fjord), according to bathymetry data (see 'Geophysical predictor variables'). The reason for not including the river-like Schlei Fjord (Fig. 1) was its strongly reduced water clarity along with high agricultural nutrient input, which prevent the growth of eelgrass in most of the fjord (Fürhaupter et al. 2003). However, model predictions were calculated for the Schlei area to find out whether additional factors might affect eelgrass distribution in the fjord.

Surface salinity in the region varies between $\sim 8$ and 26 psu (continuous logging of the German Federal Maritime and Hydrographic Agency [BSH] between 2004 and 2012), depending on the inflow of

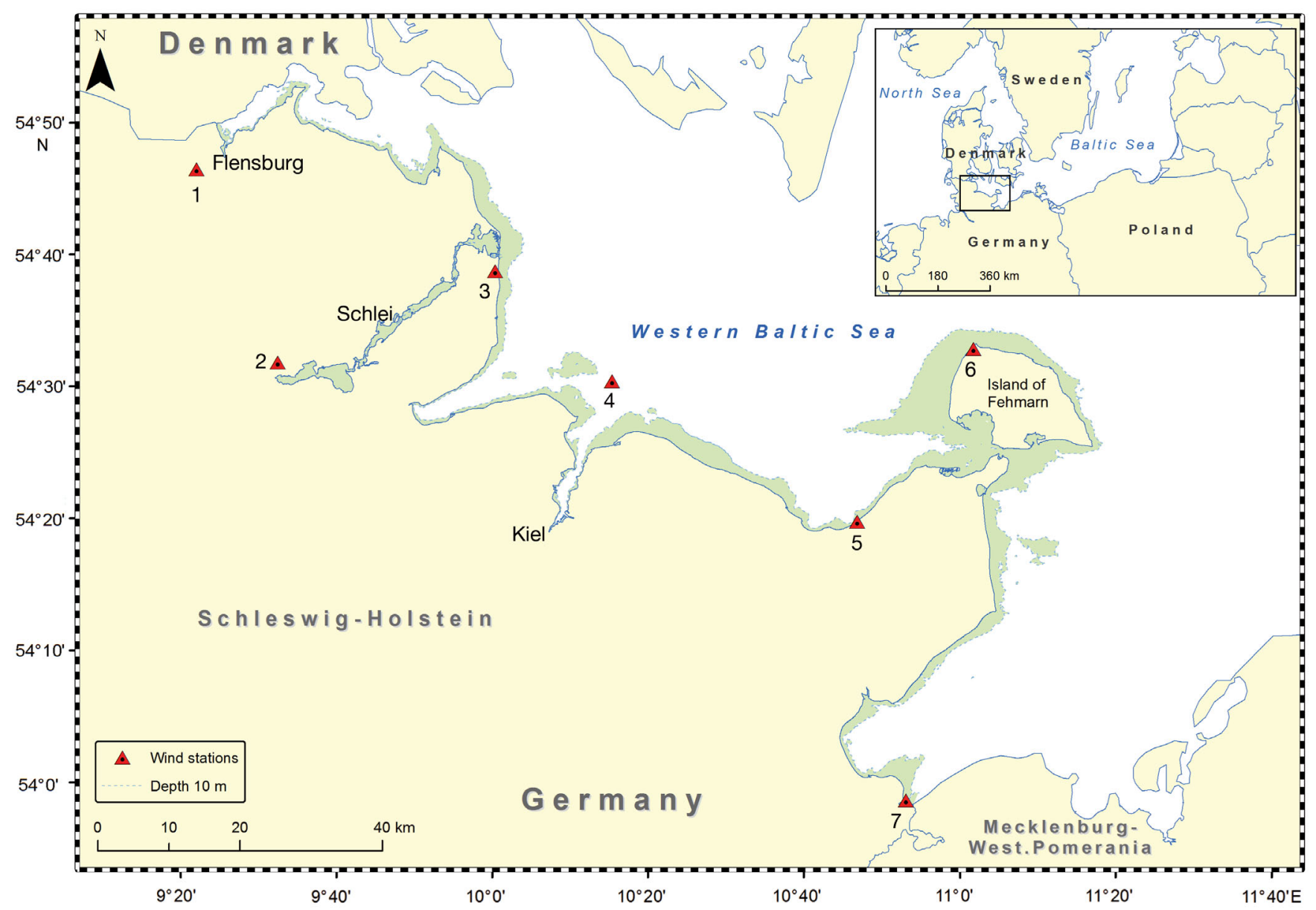

Fig. 1. Study area showing the potentially habitable depth zone for eelgrass in green (0 to $10 \mathrm{~m})$. Wind stations: 1 . Flensburg; 2. Schleswig; 3. Schönhagen; 4. Kiel Lighthouse; 5. Putlos; 6. Fehmarn; 7. Travemünde 
fully saline North Sea water, location, and depth. Tides are negligible, but wind-driven water level changes are common. Currents and wave exposure are generally weak in the study region, as it is well protected from prevailing westerly winds and is relatively enclosed. Maximum significant wave height rarely exceeds $3 \mathrm{~m}$ (Petterson et al. 2012). The climate regime is cold temperate, with water temperatures in the study region ranging from $1^{\circ} \mathrm{C}$ in $\mathrm{Fe}-$ bruary to $20^{\circ} \mathrm{C}$ in August (Siegel \& Gerth 2011). Occasionally, severe winters can lead to the formation of sea ice in the region. Geologically, the study region is a 'fjord coast', with fjords (Eckernförder Bay and Kiel, Schlei, and Flensburg), bays, sandy coasts, some cliffs, and only 1 large island (Fehmarn). The study area is dominated by sandy and muddy sediments, with infrequent small to large boulders in some locations. No bedrock exists along the Baltic coast of Schleswig-Holstein. Eelgrass is common on sandy bottoms along the entire German Baltic coast (Boström et al. 2014), but precise data about its distribution, abundance, depth limits, areal extent, or meadow structure have not been published so far.

\section{Mapping}

Mapping was conducted in the summer season (between June and August) in 2010 and 2011. Eelgrass was recorded continuously along transects with an underwater towed camera (1/3 inch color chargecoupled device sensor in a waterproof housing, resolution: $512 \times 582$ pixels, sensitivity: $0.5 \mathrm{~lx}$, image angle: $92^{\circ}$, lens: $3.6 \mathrm{~mm}$ ) deployed from a small boat $(<6 \mathrm{~m})$ travelling at idle speed (ca. 2 to $\left.4 \mathrm{~km} \mathrm{~h}^{-1}\right)$. The field of view depended on height of the camera above the seafloor ( 0.8 to $1.5 \mathrm{~m}$ ) and varied between 2 and $7 \mathrm{~m}^{2}$. The video signal was digitally overlaid in an onboard unit with additional data (depth, position, date, time, and transect identifier) and recorded on hard disk for further analyses. Depth, position, and time were provided by an echo sounder and a GPS receiver included in the onboard unit and recorded in a standard format (NMEA 0183 file, National Marine Electronics Association).

Video transects ran parallel and perpendicular to the shore. Parallel transects (PTs) were conducted to detect eelgrass presence or absence at a certain coastal stretch in a depth of 3 to $4.5 \mathrm{~m}$ (depth of densest eelgrass cover along German Baltic Coast, P. Schubert pers. obs.) and included virtually the entire study area. Perpendicular transects (VTs) provided information about shallow and deep depth limits (an important indicator for the WFD) and depth-dependent changes of eelgrass distribution. VTs were distributed over the length of the entire coast and ranged from about 0.5 to $10 \mathrm{~m}$ depth with lengths between 70 and $3270 \mathrm{~m}(\mathrm{n}=110)$, depending on slope of the coast. The distance between single VTs was approximately $2 \mathrm{~km}$. The videos of both transect types covered approximately $400 \mathrm{~km}$ of seafloor (PTs: 315 km, VTs: 84 km).

Eelgrass coverage and additional observations (sediment type, algae and blue mussel occurrence) were assessed continuously by examination of the video on a computer screen. These observations were then automatically combined with the NMEA data using a specifically designed computer program (unpubl. program: GAZER, by W. Hukriede \& P. R. Schubert), which produced a protocol file for further analyses. Spatiotemporal resolution for single observations was thus dependent on velocity of the boat and frequency of GPS measurements, which was between 0.25 and $1 \mathrm{~Hz}$, resulting in variable distances between single observations along transects of 1 to $5 \mathrm{~m}$. Eelgrass cover along the transects was estimated semi-quantitatively by applying an extended Braun-Blanquet (1964) 6-class scale of $0,<10,10$ to 25,25 to 50,50 to 75 , and 75 to $100 \%$. Because of the large amount of video data, 4 different observers were assigned to this task. Intercalibration showed that results for individual observers did not differ significantly when cover classes were used (data not shown). Presence/absence observations used for modeling were indiscernible between observers.

Eelgrass patchiness on a meter scale was calculated using Montefalcone's patchiness index (PI) (Montefalcone et al. 2010), referred to as 'grain' by Pielou (1977). To calculate the index, presence/ absence data from PTs were used. We defined the PI to be the number of 0 to 1 or 1 to 0 transitions per $500 \mathrm{~m}$ of straight-line transect length. Additionally, the mean length of patches and median cover class of eelgrass were computed for every $500 \mathrm{~m}$ section along the coast. Differences between mean patch lengths of exposed versus sheltered sections were assessed with a 2-sample $t$-test.

\section{Modeling}

The species distribution model (SDM) for eelgrass was fitted using generalized additive models (GAMs, Hastie \& Tibshirani 1990) and a set of 3 predictor variables (depth, slope, and wave exposure, see 'Geophysical predictor variables'). GAMs are a semi- 
parametric extension of generalized linear models (Hastie \& Tibshirani 1990), and their ability to fit complex non-linear responses has made GAMs one of the most used SDM methods in the recent past (Downie et al. 2013). The model's parameters were calculated applying the generalized regression analysis and spatial prediction (GRASP) software package (Lehmann et al. 2002) within R (R Development Core Team 2008). To avoid a bias from the variable distance between observations during the 2 yr survey (see 'Mapping'), distances were standardized to $5 \mathrm{~m}$ for the model input. Where needed, GPS position and predictor variables were interpolated between 2 neighboring readings (max. interpolated distance $=$ $5 \mathrm{~m}$ ). Data about eelgrass occurrence (presence/ absence) were taken directly from the protocol file and were not interpolated.

To obtain a sound database for the modeling process, observations with erroneous or missing depth data were removed. We then applied 2 filters on the database (all observations: $n=70704$ ). (1) To achieve a balanced depth distribution, we reduced the skew of depth data originating from the predominance of PTs in the depth range of 3 to $4.5 \mathrm{~m}$ (Table 1). To this end, the number of all surplus observations in the 9 depth classes from 0 to $9 \mathrm{~m}$ was randomly reduced to match the number of observations in the 1 to $2 \mathrm{~m}$ depth class $(\mathrm{n}=1924)$. For the 2 edge depth classes of 0 to 1 and 8 to $9 \mathrm{~m}$ that had fewer observations ( $\mathrm{n}=$ 267 and $n=593$, respectively), all observations were used for our model, resulting in a total of $n=14328$ observations after applying the first filter. (2) We randomly excluded 6504 absences from the observation data to avoid the adverse consequences of a large number of absences (Lehmann et al. 2002) and to obtain the recommended balanced prevalence with similar numbers of absences and presences (Liu et al. 2005). The ensuing prevalence equality enabled us to translate eelgrass prediction values directly into

Table 1. Number of all observations of eelgrass presence/ absence per depth class

\begin{tabular}{|cr|}
\hline Depth class $(\mathrm{m})$ & $\mathrm{n}$ \\
\hline $0-1$ & 267 \\
$1-2$ & 1924 \\
$2-3$ & 9759 \\
$3-4$ & 25653 \\
$4-5$ & 20594 \\
$5-6$ & 5667 \\
$6-7$ & 3623 \\
$7-8$ & 2565 \\
$8-9$ & 593 \\
\hline
\end{tabular}

probabilities of encounter without further modification (Liu et al. 2005). After applying the second filter, 7824 observations were left for the modeling process.

Finally, correlations between the 3 chosen predictors (see 'Geophysical predictor variables') were calculated to ascertain the avoidance of functional dependencies between predictors, which would be misleading when estimating the model (Lehmann et al. 2002). However, correlations between any pairs of predictor variables were weak and non-significant (all $\mathrm{R}^{2}<0.08$ ); thus, no predictor had to be removed from the modeling process.

To estimate the total area of eelgrass in the study region, the modeled probability to find eelgrass at a certain location (0 to 0.95) was multiplied with the area for the prediction. Resolution of the model was $100 \mathrm{~m}$, resulting in an area of prediction of $10000 \mathrm{~m}^{2}$ for each point within the prediction grid.

\section{Geophysical predictor variables}

In our SDM, the variables depth, slope, and wave exposure determined the response variable (probability of eelgrass occurrence). Additional predictors (salinity, temperature, and sediment class) did not have significant influence on the response variable and were not incorporated in the model (data not shown).

Water depths along the surveyed transects were measured in the field with an echosounder (EchoPilot Bronze Depth+, frequency: $150 \mathrm{kHz}$, accuracy: $0.1 \mathrm{~m})$. Depths for non-surveyed locations were derived from a digital elevation model (DEM) of the southwestern Baltic Sea with a horizontal resolution of $50 \mathrm{~m}$. The DEM was provided by the State Agency for Agriculture, Environment and Rural Areas Schleswig-Holstein (LLUR; 2004) and is based on a depth survey of the BSH in 2002 and a digital topography of the Leibniz Institute for Baltic Sea Research Warnemünde (IOW). The coast's slope was calculated from the DEM using the ArcGIS Spatial Analyst slope tool, with a horizontal resolution of $50 \mathrm{~m}$. Wave exposure was modeled following the procedure described by Ekebom et al. (2003), which quantifies wave exposure as apparent wave power in watts. For these calculations, we used fetch (capped at $30 \mathrm{~km}$ ) and wind speed, both for 36 directions of the compass rose, in the period from 1998 to 2011 (14 yr). Wind data for every grid point (resolution: $100 \mathrm{~m}$ ) were obtained from the nearest of 7 weather stations from the German Weather Service (DWD) and GEOMAR (only data from the Kiel lighthouse). Wind speed was 
Table 2. Model selection based on Akaike's information criterion (AIC). Results sorted with ascending AIC values (i.e. descending model performance). The response variable is Zostera marina occurrence (presence/ absence), and the predictor variables are depth, slope, and wave exposure (WE) comparing average and threshold wind speeds with selected threshold velocities. $\Delta$ is the difference from the best model. Receiver-operator characteristic curve/associated area under the curve (ROC/AUC) denotes the results of the area under the ROC curve for each model (AUC $<0.7$ : poor; 0.7 to 0.8 : satisfactory; 0.8 to 0.9 : very good $>0.9$ : excellent discriminative ability). avg.: average

\begin{tabular}{|c|c|c|c|c|}
\hline Rank & Predictor variable & $\mathrm{AIC}$ & $\Delta$ & ROC/AUC \\
\hline 1 & Depth + Slope + WE $\left(\geq 6 \mathrm{~m} \mathrm{~s}^{-1}\right)$ & 8074.7 & 0.0 & 0.8207 \\
\hline 2 & Depth + Slope + WE $\left(\geq 7 \mathrm{~m} \mathrm{~s}^{-1}\right)$ & 8089.9 & 15.2 & 0.8199 \\
\hline 3 & Depth + Slope + WE $\left(\geq 5 \mathrm{~m} \mathrm{~s}^{-1}\right)$ & 8095.9 & 21.2 & 0.8192 \\
\hline 4 & Depth + Slope + WE $\left(\geq 8 \mathrm{~m} \mathrm{~s}^{-1}\right)$ & 8125.1 & 50.4 & 0.8177 \\
\hline 5 & Depth + Slope + WE $\left(\geq 4 \mathrm{~m} \mathrm{~s}^{-1}\right)$ & 8129.8 & 55.1 & 0.8166 \\
\hline 6 & Depth + Slope + WE $\left(<10 \mathrm{~m} \mathrm{~s}^{-1}\right)$ & 8147.0 & 72.3 & 0.8159 \\
\hline 7 & Depth + Slope + WE (avg.) & 8215.8 & 141.1 & 0.8115 \\
\hline 8 & Depth + WE $\left(\geq 6 \mathrm{~m} \mathrm{~s}^{-1}\right)$ & 8305.9 & 231.2 & 0.8052 \\
\hline 9 & Depth + WE (avg.) & 8454.5 & 379.8 & 0.7961 \\
\hline 10 & Depth + Slope & 8779.8 & 705.1 & 0.7728 \\
\hline 11 & Depth & 8982.8 & 908.1 & 0.7559 \\
\hline 12 & Slope + WE $\left(\geq 6 \mathrm{~m} \mathrm{~s}^{-1}\right)$ & 9957.4 & 1882.7 & 0.6884 \\
\hline 13 & $\mathrm{WE}\left(\geq 6 \mathrm{~m} \mathrm{~s}^{-1}\right)$ & 10032.0 & 1957.3 & 0.6733 \\
\hline 14 & Slope + WE (avg.) & 10116.0 & 2041.3 & 0.6637 \\
\hline 15 & WE (avg.) & 10189.0 & 2114.3 & 0.6574 \\
\hline 16 & Slope & 10727.0 & 2652.3 & 0.5725 \\
\hline
\end{tabular}

made with 5 subsets (folds) of the entire dataset (5-fold cross-validated ROC, cVROC). To estimate the precision of the AUC and to obtain confidence intervals, bootstrap resampling of the entire dataset (4000 iterations) was applied (Efron 1979). The AUC value of ROC plots can take values between 0.5 and 1.0. Following the classification of Hosmer \& Lemeshow (2000), values $<0.7$ are regarded as having a poor discriminative ability; 0.7 to 0.8 , a satisfactory discriminative ability; 0.8 to 0.9 , a very good discriminative ability; and $>0.9$, an excellent discriminative ability.

Besides correctly predicted presences and absences, even the best SDM will make false predictions for both types of observations. These false predictions are normally summarized in a confusion matrix (Table 3) and can hold interesting information. In the case of abundant eelgrass, falsely predicted presences merit attention, as they could indicate locations well suited for potential restoration of eelgrass meadows. Following the pre-

time averaged from $1 \mathrm{~h}$ (DWD) or $8 \mathrm{~min}$ (GEOMAR) values and measured in meters per second. In addition to the average wind speed, wave exposure was calculated for different wind speeds below and above iterated thresholds, with steps of $1 \mathrm{~m} \mathrm{~s}^{-1}$. To find the best model, all wind speeds were tested and validated. Wave exposure values calculated with wind speeds above $6 \mathrm{~m} \mathrm{~s}^{-1}$ scored highest in Akaike's information criterion (AIC) values (Table 2) and were incorporated into the final model.

\section{Model fitting and validation}

As a tool for model selection, we used AIC (see Burnham \& Anderson 2001) within the GRASP package. The AIC procedure allows the ranking of candidate models relative to each other according to parsimony and goodness of fit. Of all candidate models, the resulting final model (Model 1, Table 2) was used to predict spatial distribution of eelgrass.

To protect against over-parameterization, the final SDM was verified applying a cross-validation method, with the threshold-independent receiveroperating characteristic (ROC) curve (Fielding \& Bell 1997) and its associated area under the curve (AUC) as the statistic of interest. The cross-validation was cautionary principle, a threshold of $5 \%$ probability of error in predicting the presence of eelgrass was employed to define falsely predicted presences and locate potential restoration sites. For the confusion matrix, a threshold of 0.48 (= highest kappa, к) was chosen, assuming that both error types (falsely predicted absences and falsely predicted presences) are equivalent (Fielding \& Bell 1997).

\section{RESULTS}

\section{Mapping results}

We found that eelgrass grew along most (80\%) of the coastline in the study area, with just a few areas

Table 3. Confusion matrix of the final model showing the observed and predicted presences/absences and respective percentages at a threshold of 0.48 (kappa, $\kappa)$. Correct classification rate at this threshold is $73.9 \%$

\begin{tabular}{|lcc|}
\hline & $\begin{array}{c}\text { Observed } \\
\text { presence }\end{array}$ & $\begin{array}{c}\text { Observed } \\
\text { absence }\end{array}$ \\
\hline $\begin{array}{l}\text { Predicted presence } \\
\text { Predicted absence }\end{array}$ & $\begin{array}{c}3137(40.1 \%) \\
775(9.9 \%)\end{array}$ & $1267(16.2 \%)$ \\
$2645(33.8 \%)$ \\
\hline
\end{tabular}




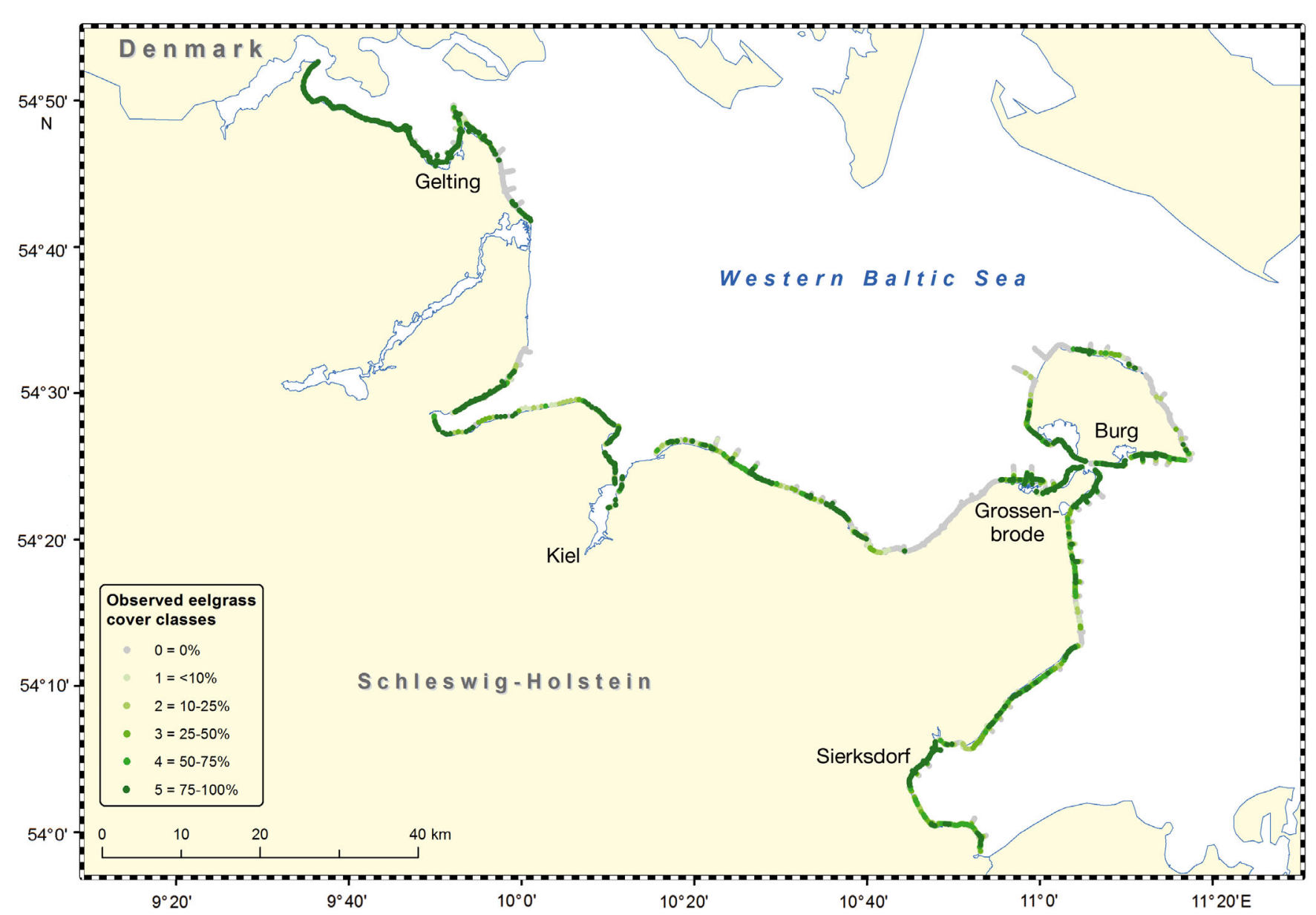

Fig. 2. Observed eelgrass cover along surveyed camera transects. Eelgrass cover is shown in 6 classes (class 0: $0 \%$; class 1: $<10 \%$; class 2: 10 to $25 \%$; class 3: 25 to $50 \%$; class 4: 50 to $75 \%$; class 5: 75 to $100 \%$ ). Place names given for selected locations. Transect width is not to scale

as exceptions (Fig. 2). Of the $315 \mathrm{~km}$ surveyed transect length along the shore, $63 \mathrm{~km}$ exhibited no eelgrass $(20 \%)$. Dense eelgrass meadows $(\geq 50 \%$ cover $)$ populated about $70 \mathrm{~km} \mathrm{(22 \% )} \mathrm{of} \mathrm{mostly} \mathrm{sheltered}$ coastline. Eelgrass depth limits of meadows (meadow definition: eelgrass cover $\geq 10 \%$ ) were assessed along 110 VTs, 97 of which featured eelgrass meadows. The deep depth limit ranged between 2.2 and $7.6 \mathrm{~m}$ (mean $=5.3 \mathrm{~m}, \mathrm{SD}=1.27, \mathrm{n}=97$ ), while the shallow depth limit was between 0.6 and $5.7 \mathrm{~m}$ (mean $=2.3 \mathrm{~m}$, $\mathrm{SD}=1.27$, Fig. 3). With only a few exceptions, both depth limits were shallower in fjords, bays, and other sheltered locations than in moderately or highly exposed locations on open coastlines and headlands.

The patchiness index (PI) for eelgrass, measured as transitions between eelgrass and no eelgrass per $500 \mathrm{~m}$ of transect length ('section'), ranged between 0 and 68 (mean $=16.1, \mathrm{SD}=12.7, \mathrm{n}=482$ ). $\mathrm{PI}=0$, meaning that 1 patch covered the entire section, was found at 30 of 482 sections, all situated inside fjords

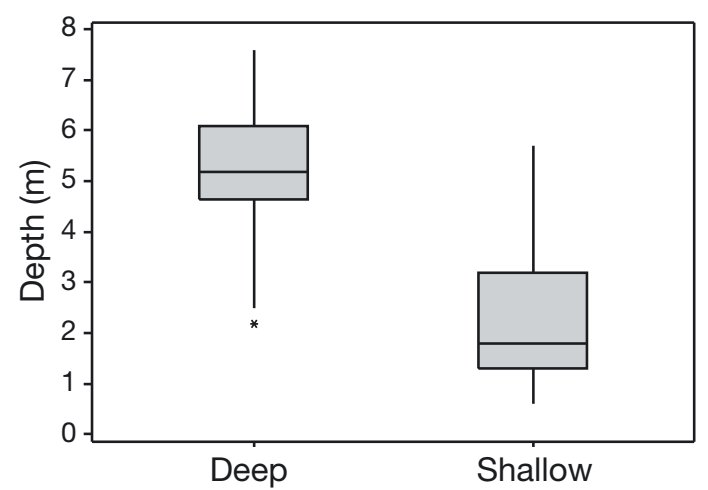

Fig. 3. Box plot of depth limit range for deep and shallow depth limits along perpendicular mapping transects with eelgrass $(n=97)$, showing median (centre line), 1st to 3rd quartiles (box limits), range of values (whiskers) and outliers $\left({ }^{*}\right)$

and bays. Mean calculated wave exposure for these 30 sections was $273.4 \mathrm{~W}(\mathrm{SD}=200.9 \mathrm{~W}, \mathrm{n}=30$ ), compared to an overall mean wave exposure for all sections of 430.4 W ( $\mathrm{SD}=253.0 \mathrm{~W}, \mathrm{n}=482)$. Mean patch 
Table 4. Descriptive statistics of predictor variables depth, wave exposure, and slope separated for eelgrass presences and absences and their contributions to the final model (Model 1, Table 2)

\begin{tabular}{|c|c|c|c|c|c|c|c|c|c|c|c|c|c|}
\hline \multirow{2}{*}{ Predictor } & \multicolumn{6}{|c|}{ Eelgrass presence } & \multicolumn{6}{|c|}{ - Eelgrass absence } & \multirow{2}{*}{$\begin{array}{c}\text { Model } \\
\text { contrib- } \\
\text { ution }(\%)\end{array}$} \\
\hline & $\mathrm{n}$ & Mean & $\mathrm{SD}$ & Min. & Median & Max. & $\mathrm{n}$ & Mean & SD & Min. & Median & Max. & \\
\hline Depth (m) & 3912 & 3.462 & 1.476 & 0.000 & 3.200 & 8.116 & 3912 & 4.989 & 2.180 & 0.000 & 5.191 & 8.931 & 66.3 \\
\hline Wave exposure (W) & 3912 & 339.2 & 244.2 & 9.3 & 279.0 & 1379.7 & 3912 & 515.4 & 330.5 & 18.0 & 441.1 & 1509.0 & 29.2 \\
\hline Slope $\left({ }^{\circ}\right)$ & 3912 & 0.792 & 0.687 & 0.020 & 0.571 & 3.545 & 3912 & 0.744 & 0.660 & 0.011 & 0.564 & 3.509 & 4.6 \\
\hline
\end{tabular}

length for all sections was $128.6 \mathrm{~m}(\mathrm{SD}=286.5 \mathrm{~m}, \mathrm{n}=$ 482), with maximum patch lengths of $>2000 \mathrm{~m}$ found off Gelting, Sierksdorf, Burg (Fehmarn), and Grossenbrode (Fig. 2). Minimum patch lengths of 1 to $5 \mathrm{~m}$ were found mainly at exposed coasts. Mean patch length of sections from the upper half of the wave exposure range was significantly smaller than mean patch length from the lower half (74 versus $294 \mathrm{~m}$, $t$-test: $\mathrm{n}=482, t=5.85, \mathrm{p}<0.0001)$. The median of all 482 of the $500 \mathrm{~m}$ sections was in class 2 , equivalent to a cover of 10 to $25 \%$.

\section{Modeling results}

Mapping results were complemented by our modeling results, which enabled us to appoint driving factors of eelgrass distribution and estimate the total eelgrass area. AIC calculations within the GRASP software confirmed the presumption that incorporating all 3 geophysical predictor variables (depth, slope, and wave exposure) led to the best modeling results (Table 2). Models integrating the predictor 'wave exposure' (WE) with wind speeds exceeding certain thresholds (Models 1 to 5) scored consistently higher than either those with averaged wind speeds (Model 7) or those with wind speeds below certain thresholds (Model 6). Besides producing different AIC values, the models' visual appearances as maps revealed substantial and meaningful differences in eelgrass distribution for models with wind speeds exceeding certain thresholds compared to those with winds below certain thresholds (data not shown). These differences are in good accordance with our mapping results and confirm that eelgrass distribution is mainly shaped by stronger winds.

Contributions of the respective predictors to the final model (Model 1, Table 2), calculated as amount of explained variation that each predictor variable contributed to the model, were $66.3 \%$ for depth, $29.2 \%$ for wave exposure, and $4.6 \%$ for slope (Table 4). This predictor hierarchy was mirrored in the AIC values for different models (Table 2): dropping only slope from the model (Models 8 and 9) led to a higher ranking than dropping either WE (Model 10) or depth (Models 12 and 14). The same ranking ensued when the model was built with just 1 predictor: integrating depth alone (Model 11) led to a better model than WE alone (Models 13 and 15); slope alone (Model 16) scored lowest.

Results of the 5-fold cvROC of our final model showed an AUC of 0.81908 (95\% confidence interval: 0.81894 to 0.81923$)$, indicating a very good discriminative ability (after Hosmer \& Lemeshow 2000). GAM response curves of each of the 3 predictor variables (Fig. 4) showed how environmental gradients shape eelgrass distribution in the western Baltic. Response of eelgrass to depth was bell shaped, with an optimal depth for eelgrass in the study region between 2 and $4 \mathrm{~m}$. Response to slope showed a clear minimum at ca. $1.1^{\circ}$, with more positive responses for both flatter and steeper inclinations. Wave exposure
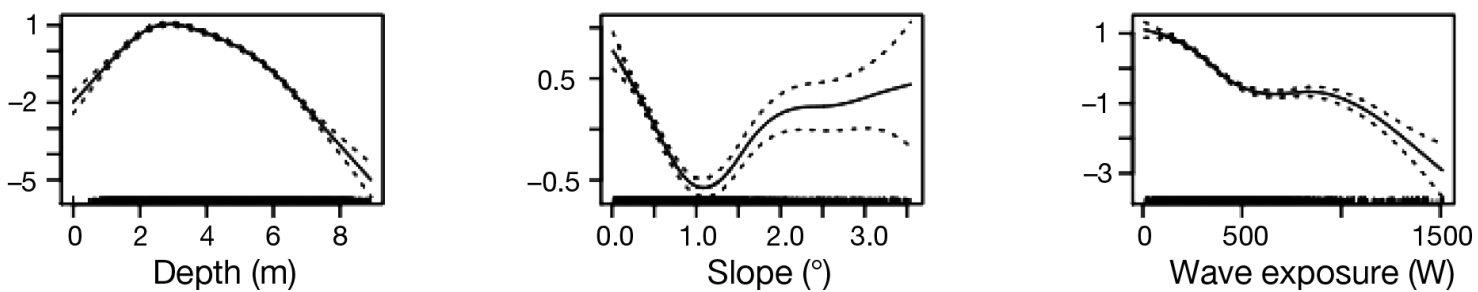

Fig. 4. Response curves of eelgrass presence/absence to the predictor variables depth, slope, and wave exposure in the generalized additive model analysis for the final model (Model 1). The $y$-axis represents the additive contribution of each variable (range differs between panels). Black ticks above $x$-axis represent observation range. Dashed lines represent $95 \%$ confidence interval limits 


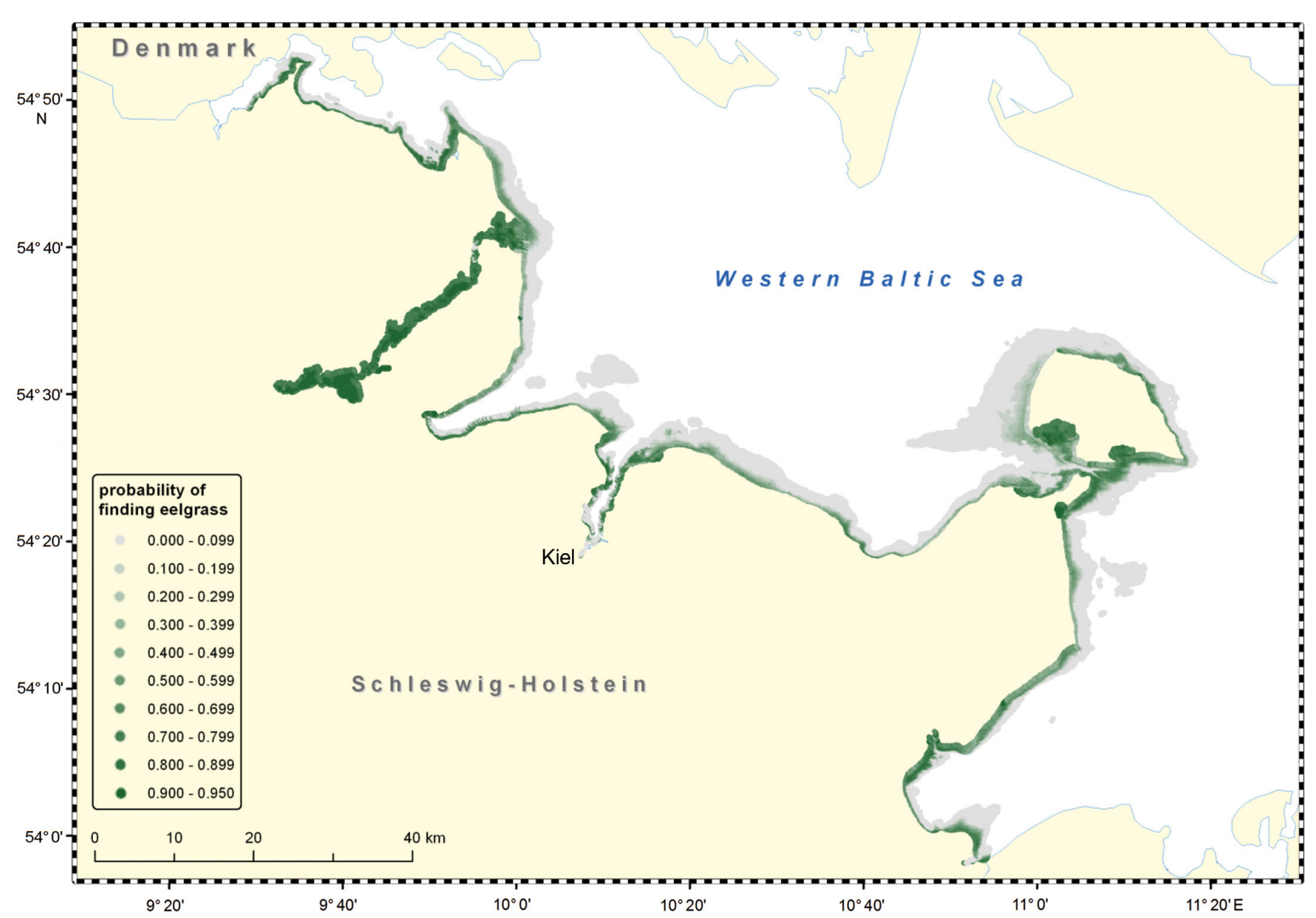

Fig. 5. Predicted probability of eelgrass occurrence along the coast of Schleswig-Holstein for the final model (Model 1). The darker green the area, the larger the probability to find eelgrass. Horizontal resolution of the model is $100 \mathrm{~m}$; maximum depth is $10 \mathrm{~m}$

was clearly negatively correlated with eelgrass occurrence; however, no change in the response variable was apparent within a small range at medium exposures (500 to 1000 W) (Fig. 4).

The resulting prediction map for our final model in the study region had a horizontal resolution of $100 \mathrm{~m}$ and encompassed areas with a depth of up to $10 \mathrm{~m}$ (Fig. 5). The calculated total area populated with eelgrass summed up to $140.49 \mathrm{~km}^{2}$ or $23.91 \%$ of the entire potentially habitable depth zone for eelgrass (depth 0 to $10 \mathrm{~m}$, area: $587.58 \mathrm{~km}^{2}$ ).

Predicted and observed presences/absences at a threshold of 0.48 are summarized in the confusion matrix (Table 3). The ensuing correct classification rate for this threshold is $73.9 \%$. By putting more importance to falsely predicted presences and applying a more conservative threshold of $5 \%$ probability of error at 194 surveyed locations, eelgrass was falsely predicted as being present. These falsely predicted presences spread over the entire surveyed coast (Fig. 6). With just a few exceptions in Lübeck Bay, most of these locations lay in sheltered areas with large eelgrass meadows, owing to small-scale variation below the model's (and its predictors') resolution. Thus, only a relatively few falsely predicted presences to suggest possible restoration sites were encountered. Promising areas are situated at the inner Eckernförde Bay, the east coast of Fehmarn, and off Brodten Cliff (Fig. 6).

\section{DISCUSSION}

To the best of our knowledge, our study is the most data-rich underwater survey of submersed vegetation undertaken to date. We found that the area covered by sublittoral seagrass beds along the northern German Baltic coast is comparable to the areal extent of (mostly intertidal) seagrass beds in the Wadden Sea (Dolch et al. 2013), but because of differences in 


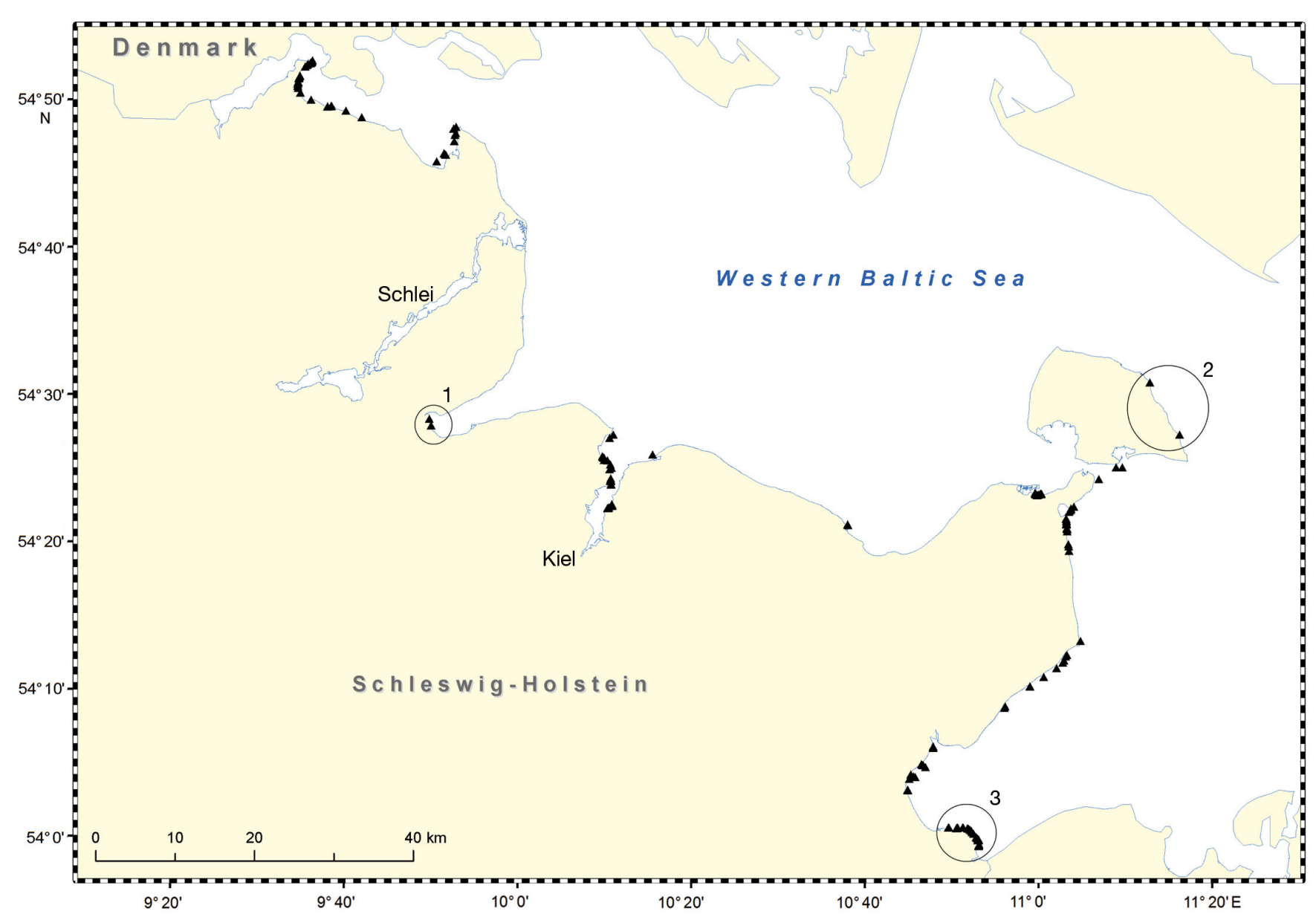

Fig. 6. Falsely predicted presences (with $5 \%$ probability of error in predicting the presence of eelgrass) for the final model (Model 1). Small triangles show locations where eelgrass is absent, although the modeled probabilities to find eelgrass are high (>0.77). Circles ring potential restoration sites (1: Eckernförde Bay; 2: Fehmarn-East; 3: Brodten Cliff). The Schlei Fjord was excluded from the analysis

growth form and seagrass species, total biomass of western Baltic Sea populations is expected to surpass North Sea populations by far. The areal extent comprises about $140 / 1222 \mathrm{~km}^{2}=11.5 \%$ of all known Baltic seagrass beds and $140 / 1482 \mathrm{~km}^{2}=9.4 \%$ of northern European seagrass populations (Boström et al. 2014). The SDM derived from our extensive database has very good predictive power and provides additional information about eelgrass distribution and possible restoration sites.

The acquisition of accurate data on eelgrass distribution in turbid waters is costly and time consuming yet indispensable for managing and monitoring purposes. Our results show that a combined approach of georeferenced video transects and subsequent SDM can overcome the weaknesses of both methods and lead to distribution maps of satisfying quality covering the entire target area. Although video mapping covers only narrow line transects of about 1 to $3 \mathrm{~m}$ width, this method provides additional information on eelgrass patchiness, exact depth limits, and health status. Moreover, additional environmental data such as sediment characteristics or macroalgae cover can be obtained. Compared to sonar techniques, which recently became more widely used to survey seagrasses (e.g. Lathrop et al. 2006, Lefebvre et al. 2009), video mapping has the advantage of a direct observation without the risk of misinterpreting results and needs no minimum cover value below which eelgrass is not detected. Despite its drawbacks, for turbid waters, video mapping remains the preferred method to map abundant and easily identifiable species like eelgrass down to their maximum colonization depth.

SDM should ideally accompany any data acquisition to fill in unsurveyed areas and develop maps of areal coverage. As an extra value, potential restora- 
tion sites can be identified. Additionally, future distribution of eelgrass in the face of predicted environmental change can be modeled and integrated into coastal managing plans and directives. For example, for the Baltic Sea region, increases in wave exposure due to changing wind speeds and directions are predicted (BACC Author Team 2008) and will likely have substantial effects on eelgrass distribution. With the model, these effects can be quantified. Concerning the model input, accurate and abundant distributional data along with concomitant physical factors (e.g. depth or wave exposure) of similar resolution in the modeled area are important prerequisites to develop useful and reliable SDMs. Our model input encompassed the entire modeled area and included all obvious environmental gradients that are present in the study region. The coastline in northern Germany has a simple geomorphology with just 1 big island and few peninsulas or inlets, facilitating a proper prediction of vegetation distribution with relatively few abiotic factors. Moreover, the basis of our SDM was exceptionally data rich, with about 8000 presence/absence data points on eelgrass, for a prediction area of $588 \mathrm{~km}^{2}$. Table 5 shows a comparison between the present and past studies concerning submarine vegetation. Of those studies, our observational input had the highest resolution. Consequently, our model's resulting response curves (Fig. 4) exhibit a high statistical confidence level, and the model's high AUC values (and narrow confidence intervals of the AUC values) indicate that it has higher predictive power than comparable models. Still, modeling results are always dependent on the quality and resolution of the predictors used. In our model, small-scale variations $(<100 \mathrm{~m})$ of eelgrass distribution are below the predictors' resolution, explaining most of the falsely predicted presences in areas with high eelgrass cover. However, the crossvalidation of the model showed that the predictions for the entire study area forecast the presence (and absence) of eelgrass with very high certainty.

Three geophysical factors were sufficient to achieve a very good predictive ability of the final model ( 5 -fold cVROC $=0.82$ ). Of the 3 factors, depth had the greatest influence on model output, followed by wave exposure and slope. The response curve shows the expected bell shape, which can be explained by an irradiance gradient (Krause-Jensen et al. 2003), depth being a proxy for light attenuation with increasing depth. Seagrasses and eelgrass in particular have relatively high light requirements (Larkum et al. 2006) and can only grow down to a compensation depth where at least $11 \%$ of surface irradiance remains (Duarte 1991). Based on our findings, this compensation depth ranges between 4 and $7 \mathrm{~m}$ in the study area and is positively correlated with the factor wave exposure. This correlation is plausible if one considers wave exposure as a proxy for water transparency (besides its other effects). With increasing exposure, high nutrient levels from human settlements or freshwater runoffs become more diluted and, hence, productivity of plankton and macroalgae decreases, leading to clearer water and less epiphyte growth on eelgrass at more exposed locations. At neighboring Danish coasts, Greve \& Krause-Jensen (2005b) showed that depth limits of eelgrass largely depend on location along an exposure gradient from inner to outer bays to open coastal waters, reflecting a corresponding gradient in water transparency. Thus, though not incorporated into the model directly, light conditions are indirectly accounted for by the factors depth and wave exposure. Nevertheless, we think that the model could have been improved by adding a fourth factor, describing light conditions, if sufficient data (e.g. from satellites) had been available. Data on light conditions would specifically help to explain the lack of eelgrass in locations that appear ideal for eelgrass according to the model prediction.

Wave exposure was found to be the second most important factor. Wave action and strong currents can lead to sediment movement, which may bury plants, expose roots and rhizomes, and even uproot entire plants (Preen et al. 1995). Hence, physical disturbance through wave action is considered one of the main extrinsic factors controlling the spatial structure of seagrass meadows (Clarke \& Kirkman 1989, Duarte et al. 1997). Wave exposure in our model is negatively correlated with the probability to find eelgrass, which corroborates other studies (Krause-Jensen et al. 2003, Downie et al. 2013, March et al. 2013a). The most exposed coastlines in the study area, such as the northwestern coast of Fehmarn or south of the Schlei Fjord, are lacking eelgrass altogether, while the most sheltered locations often feature dense and extensive meadows (Figs. 3 \& 6). Results from our patchiness analysis on a meter scale show a similar pattern, exhibiting significantly smaller patch lengths at exposed versus sheltered locations. In contrast to other regions in the world, even the most exposed stretches of our coast should facilitate eelgrass growth if only wave exposure was considered. Other surveys have demonstrated that at exposed coasts, seagrass populations tend to shift their distribution towards greater water depth, for example in the Mediterranean (Infantes et al. 2009). 


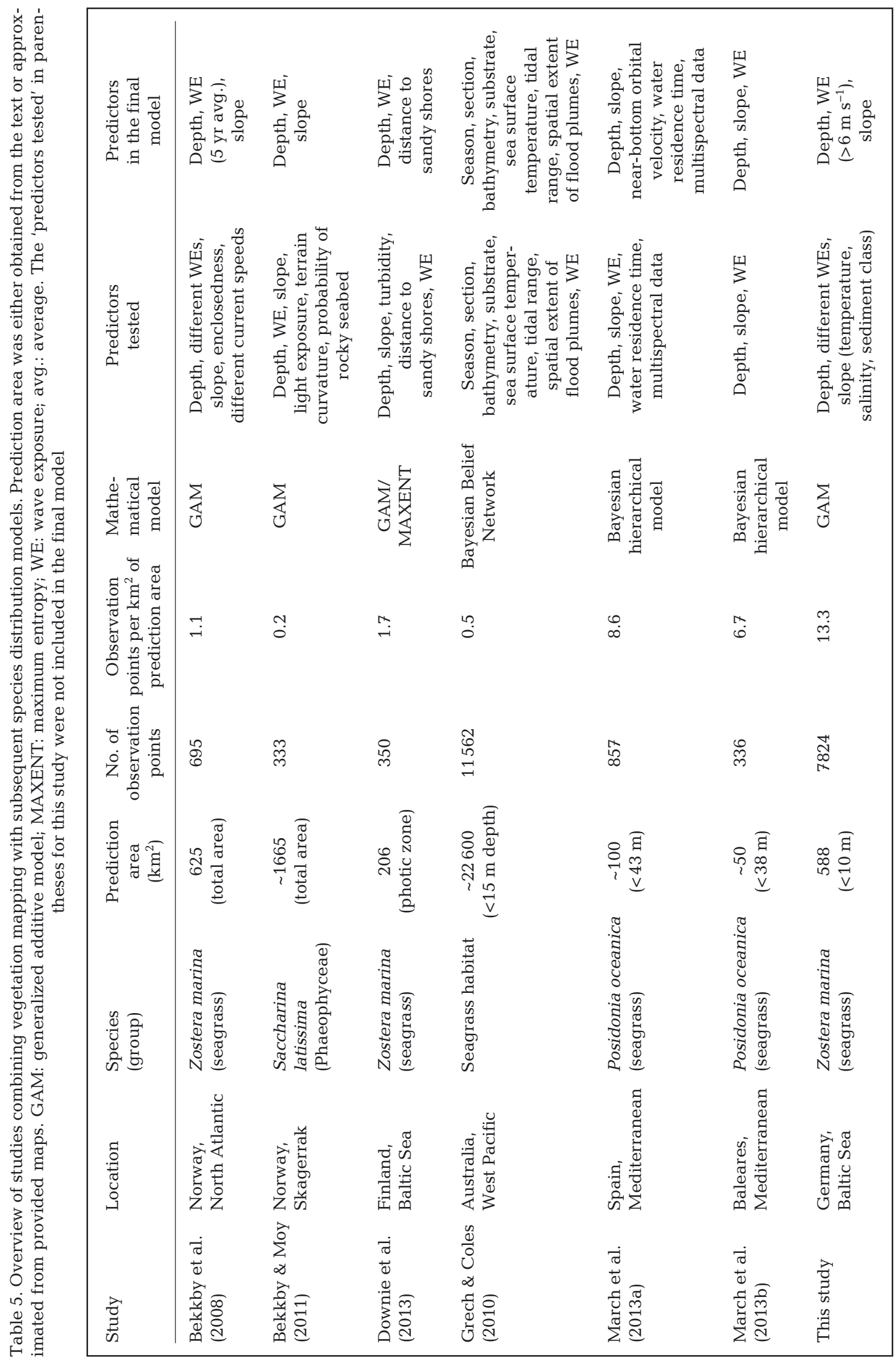


In our turbid waters, this exposure evasion is not possible, and highly exposed coasts throughout the Baltic are thus devoid of eelgrass (Boström et al. 2014).

The question remains whether these exposed areas were populated historically, before eutrophication set in in the mid- $20^{\text {th }}$ century and water clarity was much higher. Although quantitative distribution data are absent, it is likely that eelgrass was historically more abundant and occurred at greater depth in the German part of the Baltic Sea. The most detailed and comparable evidence comes from the adjacent Danish waters, where time series since 1900 show a decline in depth limits of eelgrass from an average of 4.3 to $8.5 \mathrm{~m}$ to an average of 1 to $5.4 \mathrm{~m}$ (KrauseJensen et al. 2005), resulting in an area loss of $75 \%$ (Boström et al. 2003). Secchi depth data, which are closely linked to macrophyte depth limits (Nielsen et al. 2002, Greve \& Krause-Jensen 2005a, KrauseJensen et al. 2008, 2011), show a related decrease from 9.5 to $6.0 \mathrm{~m}$ in the shallow Baltic Sea between an early (1903 to 1940) and a late (1957 to 1999) period (Dupont \& Aksnes 2013) and further strengthen the hypothesis that loss of deeper meadows since the 1960s is mainly caused by light limitation along with eutrophication (Reinke 1889, Schramm 1996, Munkes 2005, Meyer \& Nehring 2006, Schories et al. 2009). Today, maximum depth limits in our study area are less than $8 \mathrm{~m}$, with eelgrass covering about $36 \%$ of the depth zone between 0 and $8 \mathrm{~m}$. If we conservatively assume that about the same percentage of the potentially habitable area was populated historically down to a depth of $12 \mathrm{~m}$, the total area of historical eelgrass populations amounts to $288 \mathrm{~km}^{2}$, corresponding to an estimated area loss of about $148 \mathrm{~km}^{2}$ or $51 \%$ since before the 1960 s. Fortunately, Secchi depths and macroalgae depth limits have shown a slow increase over the last 2 decades in the southwestern Baltic Sea/North Sea region (Pehlke \& Bartsch 2008, Wiltshire et al. 2008, Fleming-Lehtinen \& Laamanen 2012), indicative of a reversal of the eutrophication process. Our observations confirmed these findings, showing also an increase of 1 to $1.5 \mathrm{~m}$ of the eelgrass depth limit compared to preceding studies or reports (Schories et al. 2005, Meyer \& Nehring 2006).

The river-like Schlei Fjord has a length of $42 \mathrm{~km}$ and is surrounded by farmland and pasture. Strongly reduced visibility along with high agricultural nutrient input prevent growth of eelgrass in most of the fjord, except for a small area (ca. $2.6 \mathrm{~km}^{2}$ ) around the outlet to the open sea (Fürhaupter et al. 2003). The low visibility is caused by extensive plankton pro- duction and slow exchange with the open Baltic Sea (Rieper 1976). However, historically, at least twothirds of the Schlei was populated with eelgrass (Meyer et al. 2005), and our model likewise predicts a high probability to find eelgrass throughout the Schlei (Fig. 5). The fjord comprises a total area of about $50 \mathrm{~km}^{2}$, most of which is less than $5 \mathrm{~m}$ deep, so the total eelgrass area lost in the fjord amounts to at least $30 \mathrm{~km}^{2}$.

The factor slope only had a small effect on the model output $(4.6 \%)$, but the AIC analysis suggests that this effect is sufficient to justify its inclusion in the final model (Table 2). Some studies found similar effects of slope on macrophyte distribution (Duarte \& Kalff 1990, Bekkby et al. 2008), but others did not, particularly in gently sloping terrains like in our study area (Krause-Jensen et al. 2003, Downie et al. 2013). The observability of the effects of slope in our model may be a consequence of the size of the extensive data set, which allows even minor predictors to yield a significant impact.

Given the estimated total extent of eelgrass meadows in the study area (ca. $140 \mathrm{~km}^{2}$ ), their frequent occurrence along most of the coast, and high productivity of eelgrass meadows in general (Duarte et al. 2005), eelgrass habitats form the largest and most productive coastal ecosystem in the German part of the Baltic Sea. Assumptions on productivity of eelgrass vary, depending on study region, but are generally estimated to be between 300 and $900 \mathrm{~g} \mathrm{C} \mathrm{m}^{-2}$ $\mathrm{yr}^{-1}$ (McRoy 1974, Penhale 1977, Wium-Andersen \& Borum 1984, Pedersen \& Borum 1995), leading to a rough primary production estimate between 42 and $126 \mathrm{kt} \mathrm{C} \mathrm{yr}^{-1}$ in our study area. Eelgrass meadows in the Kattegat and western Baltic region are known to have a relatively high production compared to eelgrass meadows in other regions (Boström et al. 2014). Thus, the actual primary production of eelgrass in our study area will likely be closer to the upper end of this range.

In their function as ecological engineers (sensu Wright \& Jones 2006), eelgrass meadows not only provide food and nursery ground for locally important fish species but also help to remove excess nutrients. Annual uptake of nitrogen $(\mathrm{N})$ and phosphorus (P) by eelgrass in a comparable Danish meadow was estimated to be $34.5 \mathrm{~g} \mathrm{~N} \mathrm{~m}^{-2} \mathrm{yr}^{-1}$ and $3.2 \mathrm{~g} \mathrm{P} \mathrm{m}^{-2} \mathrm{yr}^{-1}$ (Pedersen \& Borum 1993, 1995). For the eelgrass area of our study region, this would result in an annual incorporation of about $4.83 \mathrm{kt} \mathrm{N}$ $\mathrm{yr}^{-1}$ and $0.45 \mathrm{kt} \mathrm{P} \mathrm{yr}^{-1}$. Regardless of whether this amount is recycled internally, buried in the sediment, or exported to terrestrial habitats, it will not 
be available for the production of algae or plankton; thus, eelgrass nutrient uptake helps to prevent negative effects of eutrophication such as algae blooms (Hemminga et al. 1991, Dudley et al. 2001). To prevent the same amount of $\mathrm{N}$ or $\mathrm{P}$ from entering the Baltic Sea, an additional wastewater treatment plant capacity would be needed that equals 3.6 (for $\mathrm{N}$ ) or 2.3 (for P) times the largest wastewater treatment plant in Schleswig-Holstein (Klärwerk Kiel; 425000 inhabitant equivalents; location: $54.453^{\circ} \mathrm{N}, 10.185^{\circ} \mathrm{E}$; annual filter capacity: $1.34 \mathrm{kt} \mathrm{N} \mathrm{yr}^{-1}, 0.20 \mathrm{kt} \mathrm{P} \mathrm{yr}^{-1}$; M. Wuttke pers. comm.).

Patchiness of seagrass habitats is ecologically relevant and can have positive and negative effects on the associated fauna, depending on local ecological relationships and spatial scale (Boström et al. 2006). It is positively correlated with the diversity and abundance of a wide range of organisms from crustaceans to fish (McNeill \& Fairweather 1993, Eggleston et al. 1998, Salita et al. 2003, Hovel \& Fonseca 2005) and strongly reduces predation success of foraging fishes (Hovel \& Lipcius 2001). Conversely, patchier meadows are reported to exhibit lower seagrass biomass and shoot density and higher predation rate and subsequent mortality of associated clams (Irlandi 1994). Patchiness of seagrass habitat is essentially caused by external factors, mainly wave exposure and sediment characteristics (Fonseca \& Bell 1998). Seagrass landscapes have been found to be more homogenous at non-exposed and more heterogeneous and patchier at exposed disturbed sites (Fonseca \& Bell 1998, Bell et al. 1999, Frederiksen et al. 2004). Our results support these observations, showing significantly longer patch length and a lower patchiness index at more sheltered versus exposed sites. For the surveyed region as well as for an area of such size $\left(588 \mathrm{~km}^{2}\right)$, the present study provides the first estimate of eelgrass habitat patchiness, which enables further quantitative valuations of this important ecological factor.

The EU WFD aims to achieve a good environmental status in all surface and ground waters, including coastal waters up to 1 nautical mile $(=1852 \mathrm{~m}$ ) off the coastline (WFD 2000). To this end, actual status and changes of important indicator species such as eelgrass have to be monitored regularly, including in the southwestern Baltic (Fürhaupter \& Meyer 2009). With the present work, we added knowledge on eelgrass cover and depth limit from 110 VTs and $315 \mathrm{~km}$ of PTs along the coast, and for the first time, the areal extent of eelgrass could be calculated for the whole outer Baltic coastline of Schleswig-Holstein. We were able to derive a highly validated model and are now able to predict the potential of seagrass occurrence also for the areas outside our surveyed transects. For coastal management, the model allows more informed decisions and could be used instead of costly monitoring of actual occurrence.

Using the model, we currently identified 3 potential sites for eelgrass restoration in the study region. So far, there have not been any environmentally based eelgrass restoration projects in German waters (Meyer \& Nehring 2006); and there has been only 1 scientific project, which tested the practical issues of colonization success like substrate nutrient content, density, and competition within planted patches (Worm \& Reusch 2000). In the future, the EU could force member states on the basis of the WFD to actively promote water quality, e.g. by restoration of lost eelgrass habitats, a measure not uncommon in the USA (Orth et al. 2010). Our model proposes potential sites for restoration on the basis of falsely predicted presences. The influence of factors other than the 3 chosen model predictors may be responsible for the observed errors and therefore prevent a successful colonization. However, we think that our model's predictions provide a starting point for a discussion about possible locations for eelgrass restoration projects in the western Baltic Sea.

Acknowledgements. This study was funded by the State Agency for Agriculture, Environment and Rural Areas Schleswig-Holstein (LLUR). The LLUR (H.-C. Reimers) kindly provided bathymetry data for the German Baltic Sea and K. Bumke and T. Martin kindly provided the wind data from GEOMAR. We are thankful to 3 anonymous reviewers who provided useful comments and helped to improve the manuscript. We thank all snorkelers, camera operators, and boat drivers for their help in the mapping; without them, such a project would not have been possible. The arduous video analysis was done by Steffi Sokol, Pirjo Kumkar, Sarah Kaehlert, and Alice Nauendorf; we thank them for their time and patience. Special thanks to Jan Dierking for extensive input to the study. Susie Landis helped with everything else and was essential for the whole project.

\section{LITERATURE CITED}

BACC Author Team (2008) Assessment of climate change for the Baltic Sea basin. Springer-Verlag, Berlin

Backer H, Leppänen JM, Brusendorff AC, Forsius K and others (2010) HELCOM Baltic Sea Action Plan - a regional programme of measures for the marine environment based on the Ecosystem Approach. Mar Pollut Bull 60: 642-649

Baden S, Gullstrom M, Lunden B, Pihl L, Rosenberg R (2003) Vanishing seagrass (Zostera marina, L.) in Swedish coastal waters. Ambio 32:374-377

Beck MW, Heck KL, Able KW, Childers DL and others 
(2001) The identification, conservation, and management of estuarine and marine nurseries for fish and invertebrates. Bioscience 51:633-641

Bekkby T, Moy FE (2011) Developing spatial models of sugar kelp (Saccharina latissima) potential distribution under natural conditions and areas of its disappearance in Skagerrak. Estuar Coast Shelf Sci 95:477-483

> Bekkby T, Rinde E, Erikstad L, Bakkestuen V and others (2008) Spatial probability modelling of eelgrass (Zostera marina) distribution on the west coast of Norway. ICES J Mar Sci 65:1093-1101

Bell SS, Robbins BD, Jensen SL (1999) Gap dynamics in a seagrass landscape. Ecosystems 2:493-504

Bockelmann AC, Tams V, Ploog J, Schubert PR, Reusch TBH (2013) Quantitative PCR reveals strong spatial and temporal variation of the wasting disease pathogen, Labyrinthula zosterae in northern European eelgrass (Zostera marina) beds. PLoS ONE 8:e62169

Boström C, Bonsdorff E, Kangas P, Norkko A (2002) Longterm changes of a brackish-water eelgrass (Zostera marina L.) community indicate effects of coastal eutrophication. Estuar Coast Shelf Sci 55:795-804

Boström C, Baden S, Krause-Jensen D (2003) The seagrasses of Scandinavia and the Baltic Sea. In: Green EP, Short FT (eds) World atlas of seagrasses. University of California Press, Berkeley, CA, p 27-37

> Boström C, Jackson EL, Simenstad CA (2006) Seagrass landscapes and their effects on associated fauna: a review. Estuar Coast Shelf Sci 68:383-403

Boström C, Baden S, Bockelmann AC, Dromph K and others (2014) Distribution, structure and function of Nordic eelgrass (Zostera marina) ecosystems: implications for coastal management and conservation. Aquat Conserv 24:410-434

Braun-Blanquet J (1964) Pflanzensoziologie: Grundzüge der Vegetationskunde, 3rd edn. Springer, Vienna

Burnham KP, Anderson DR (2001) Kullback-Leibler information as a basis for strong inference in ecological studies. Wildl Res 28:111-119

Christianen MJA, van Belzen J, Herman PMJ, van Katwijk MM, Lamers LPM, van Leent PJM, Bouma TJ (2013) Low-canopy seagrass beds still provide important coastal protection services. PLoS ONE 8:e62413

Clarke S, Kirkman H (1989) Seagrass dynamics. In: Larkum AW, McComb AJ, Shephard SA (eds) Biology of seagrasses: a treatise on the biology of seagrasses with special reference to the Australian region. Elsevier, New York, NY, p 304-345

Costanza R, dArge R, deGroot R, Farber S and others (1997) The value of the world's ecosystem services and natural capital. Nature 387:253-260

> Dolch T, Buschbaum C, Reise K (2013) Persisting intertidal seagrass beds in the northern Wadden Sea since the 1930s. J Sea Res 82:134-141

> Downie AL, von Numers M, Boström C (2013) Influence of model selection on the predicted distribution of the seagrass Zostera marina. Estuar Coast Shelf Sci 121-122: 8-19

> Duarte CM (1991) Seagrass depth limits. Aquat Bot 40: 363-377

> Duarte CM, Kalff J (1990) Patterns in the submerged macrophyte biomass of lakes and the importance of the scale of analysis in the interpretation. Can J Fish Aquat Sci 47: 357-363

> Duarte CM, Terrados J, Agawin NSR, Fortes MD, Bach S,
Kenworthy WJ (1997) Response of a mixed Philippine seagrass meadow to experimental burial. Mar Ecol Prog Ser 147:285-294

> Duarte CM, Middelburg JJ, Caraco N (2005) Major role of marine vegetation on the oceanic carbon cycle. Biogeosciences 2:1-8

> Dudley BJ, Gahnström AME, Walker DI (2001) The role of benthic vegetation as a sink for elevated inputs of ammonium and nitrate in a mesotrophic estuary. Mar Ecol Prog Ser 219:99-107

Dupont N, Aksnes DL (2013) Centennial changes in water clarity of the Baltic Sea and the North Sea. Estuar Coast Shelf Sci 131:282-289

Efron B (1979) Bootstrap methods: another look at the jackknife. Ann Stat 7:1-26

Eggleston DB, Etherington LL, Elis WE (1998) Organism response to habitat patchiness: species and habitatdependent recruitment of decapod crustaceans. J Exp Mar Biol Ecol 223:111-132

> Ekebom J, Laihonen P, Suominen T (2003) A GIS-based step-wise procedure for assessing physical exposure in fragmented archipelagos. Estuar Coast Shelf Sci 57: $887-898$

Elmgren R (2001) Understanding human impact on the Baltic ecosystem: changing views in recent decades. Ambio 30:222-231

Fielding AH, Bell JF (1997) A review of methods for the assessment of prediction errors in conservation presence/absence models. Environ Conserv 24:38-49

Fleming-Lehtinen V, Laamanen M (2012) Long-term changes in Secchi depth and the role of phytoplankton in explaining light attenuation in the Baltic Sea. Estuar Coast Shelf Sci 102-103:1-10

Fonseca MS, Bell SS (1998) Influence of physical setting on seagrass landscapes near Beaufort, North Carolina, USA. Mar Ecol Prog Ser 171:109-121

Frederiksen M, Krause-Jensen D, Holmer M, Laursen JS (2004) Spatial and temporal variation in eelgrass (Zostera marina) landscapes: influence of physical setting. Aquat Bot 78:147-165

Fürhaupter K, Meyer T (2009) Handlungsanweisung zum Monitoring in den äußeren Küstengewässern der Ostsee nach den Vorgaben der EU-Wasserrahmenrichtline. Auftraggeber: Landesamt für Landwirtschaft, Umwelt und ländliche Räume Schleswig-Holstein und Landesamt für Umwelt, Naturschutz und Geologie Mecklenburg-Vorpommern. Bearbeitung: MariLim, Schönkirchen

Fürhaupter K, Wilken H, Meyer T (2003) Kartierung mariner Pflanzenbestände im Flachwasser der schleswig-holsteinischen Ostseeküste. MariLim, Kiel

Grech A, Coles RG (2010) An ecosystem-scale predictive model of coastal seagrass distribution. Aquat Conserv 20: 437-444

Greve TM, Krause-Jensen D (2005a) Predictive modelling of eelgrass (Zostera marina) depth limits. Mar Biol 146: 849-858

Greve TM, Krause-Jensen D (2005b) Stability of eelgrass (Zostera marina L.) depth limits: influence of habitat type. Mar Biol 147:803-812

Guisan A, Thuiller W (2005) Predicting species distribution: offering more than simple habitat models. Ecol Lett 8: 993-1009

Hastie TJ, Tibshirani RJ (1990) Generalized additive models. Chapman \& Hall, New York, NY 
HELCOM (1998) Red list of marine and coastal biotopes and biotope complexes of the Baltic Sea, Belt Sea and Kattegat. Balt Sea Environ Proc 75

HELCOM (2009) Eutrophication in the Baltic Sea - an integrated thematic assessment of the effects of nutrient enrichment and eutrophication in the Baltic Sea region. Balt Sea Environ Proc 115

Hemminga MA, Duarte CM (2000) Seagrass ecology. Cambridge University Press, Cambridge

Hemminga M, Harrison PG, van Lent F (1991) The balance of nutrient losses and gains in seagrass meadows. Mar Ecol Prog Ser 71:85-96

Hosmer DW, Lemeshow S (2000) Applied logistic regression. Wiley-Interscience Publication, Danvers, MA

> Hovel KA, Fonseca MS (2005) Influence of seagrass landscape structure on the juvenile blue crab habitat-survival function. Mar Ecol Prog Ser 300:179-191

> Hovel KA, Lipcius RN (2001) Habitat fragmentation in a seagrass landscape: patch size and complexity control blue crab survival. Ecology 82:1814-1829

Infantes E, Terrados J, Orfila A, Cañellas B, Álvarez-Ellacuria A (2009) Wave energy and the upper depth limit distribution of Posidonia oceanica. Bot Mar 52:419-427

Irlandi EA (1994) Large- and small-scale effects of habitat structure on rates of predation: how percent coverage of seagrass affects rates of predation and siphon nipping on an infaunal bivalve. Oecologia 98:176-183

- Krause-Jensen D, Pedersen MF, Jensen C (2003) Regulation of eelgrass (Zostera marina) cover along depth gradients in Danish coastal waters. Estuaries 26:866-877

Krause-Jensen D, Greve TM, Nielsen K (2005) Eelgrass as a bioindicator under the European Water Framework Directive. Water Resour Manage 19:63-75

Krause-Jensen D, Sagert S, Schubert H, Boström C (2008) Empirical relationships linking distribution and abundance of marine vegetation to eutrophication. Ecol Indic 8:515-529

Krause-Jensen D, Carstensen J, Nielsen SL, Dalsgaard T, Christensen PB, Fossing H, Rasmussen MB (2011) Sea bottom characteristics affect depth limits of eelgrass Zostera marina. Mar Ecol Prog Ser 425:91-102

Larkum AW, Orth RRJ, Duarte CM (2006) Seagrasses: biology, ecology, and conservation. Springer, Dordrecht

- Lathrop RG, Cole M, Senyk N, Butman B (2006) Seafloor habitat mapping of the New York Bight incorporating sidescan sonar data. Estuar Coast Shelf Sci 68:221-230

Lefebvre A, Thompson CEL, Collins KJ, Amos CL (2009) Use of a high-resolution profiling sonar and a towed video camera to map a Zostera marina bed, Solent, UK. Estuar Coast Shelf Sci 82:323-334

> Lehmann A, Overton JM, Leathwick JR (2002) GRASP: generalized regression analysis and spatial prediction. Ecol Modell 157:189-207

Liu C, Berry PM, Dawson TP, Pearson RG (2005) Selecting thresholds of occurrence in the prediction of species distributions. Ecography 28:385-393

Mangi SC, Davis CE, Payne LA, Austen MC, Simmonds D, Beaumont NJ, Smyth T (2011) Valuing the regulatory services provided by marine ecosystems. Environmetrics 22:686-698

> March D, Alós J, Cabanellas-Reboredo M, Infantes E, Jordi A, Palmer M (2013a) A Bayesian spatial approach for predicting seagrass occurrence. Estuar Coast Shelf Sci 131:206-212

March D, Alós J, Cabanellas-Reboredo M, Infantes E,
Palmer M (2013b) Probabilistic mapping of Posidonia oceanica cover: a Bayesian geostatistical analysis of seabed images. Aquat Bot 106:14-19

McNeill S, Fairweather PG (1993) Single large or several small marine reserves? An experimental approach with seagrass fauna. J Biogeogr 20:429-440

> McRoy CP (1974) Seagrass productivity: carbon uptake experiments in eelgrass, Zostera marina. Aquaculture 4: 131-137

Meyer T, Nehring S (2006) Anpflanzungen von Seegraswiesen (Zostera marina L.) als interne Maßnahme zur Restaurierung der Ostsee. Rostock Meeresbiol Beitr 15: 105-119

Meyer T, Reincke T, Wilken H, Fürhaupter K, Krause S, Linke A (2005) Historische Kartierungen mehrjähriger mariner Pflanzenbestände der schleswig-holsteinischen Ostseeküste. MariLim, Kiel

Moksnes PO, Gullstrom M, Tryman K, Baden S (2008) Trophic cascades in a temperate seagrass community. Oikos 117:763-777

Montefalcone M, Parravicini V, Vacchi M, Albertelli G, Ferrari M, Morri C, Bianchi CN (2010) Human influence on seagrass habitat fragmentation in NW Mediterranean Sea. Estuar Coast Shelf Sci 86:292-298

MSFD (Marine Strategy Framework Directive) (2008) Directive 2008/56/EC of the European Parliament and of the Council of 17 June 2008 establishing a framework for community action in the field of marine environmental policy. Off J Eur Communities L 164:19-22

> Munkes B (2005) Eutrophication, phase shift, the delay and the potential return in the Greifswalder Bodden, Baltic Sea. Aquat Sci 67:372-381

> Nielsen SL, Sand-Jensen K, Borum J, Geertz-Hansen O (2002) Depth colonization of eelgrass (Zostera marina) and macroalgae as determined by water transparency in Danish coastal waters. Estuaries 25:1025-1032

> Orth RJ, Carruthers TJB, Dennison WC, Duarte CM and others (2006) A global crisis for seagrass ecosystems. Bioscience 56:987-996

Orth RJ, Marion SR, Moore KA, Wilcox DJ (2010) Eelgrass (Zostera marina L.) in the Chesapeake Bay region of mid-Atlantic coast of the USA: challenges in conservation and restoration. Estuar Coast 33:139-150

Pedersen MF, Borum J (1993) An annual nitrogen budget for a seagrass Zostera marina population. Mar Ecol Prog Ser 101:169-177

Pedersen MF, Borum J (1995) Phosphorus recycling in the seagrass Zostera marina L. In: Eleftheriou A, Ansell AD, Smith CJ (eds) Biology and ecology of shallow coastal waters. Proc 28th Eur Mar Biol Symp, Crete, Greece, 23-28 September 1993. Olsen \& Olsen, Fredensborg, p 45-50

> Pehlke C, Bartsch I (2008) Changes in depth distribution and biomass of sublittoral seaweeds at Helgoland (North Sea) between 1970 and 2005. Clim Res 37:135-147

> Penhale PA (1977) Macrophyte-epiphyte biomass and productivity in an eelgrass (Zostera marina L.) community. J Exp Mar Biol Ecol 26:211-224

Petterson H, Lindow H, Dieter S (2012) Wave climate in the Baltic Sea in 2011. www.helcom.fi/baltic-sea-trends/ environment-fact-sheets/ (accessed on 14 May 2014)

Pielou E (1977) Mathematical ecology. John Wiley \& Sons, New York, NY

> Preen AR, Long WJL, Coles RG (1995) Flood and cyclone related loss, and partial recovery, of more than $1000 \mathrm{~km}^{2}$ 
of seagrass in Hervey Bay, Queensland, Australia. Aquat Bot 52:3-17

R Development Core Team (2008) R: a language and environment for statistical computing. R Foundation for Statistical Computing, Vienna

Reinke J (1889) Algenflora der westlichen Ostsee deutschen Antheils. Eine systematisch-pflanzengeographische Studie. Schmidt \& Klaunig, Kiel

Reusch TBH, Ehlers A, Hammerli A, Worm B (2005) Ecosystem recovery after climatic extremes enhanced by genotypic diversity. Proc Natl Acad Sci USA 102:2826-2831

Rieper M (1976) Investigations on the relationships between algal blooms and bacterial populations in the Schlei Fjord (western Baltic Sea). Helgol Wiss Meeresunters 28: $1-18$

Robbins BD, Bell SS (1994) Seagrass landscapes: a terrestrial approach to the marine subtidal environment. Trends Ecol Evol 9:301-304

Rönnbäck P, Kautsky N, Pihl L, Troell M, Soerqvist T, Wennhage H (2007) Ecosystem goods and services from Swedish coastal habitats: identification, valuation, and implications of ecosystem shifts. Ambio 36:534-544

Salita JT, Ekau W, Saint-Paul U (2003) Field evidence on the influence of seagrass landscapes on fish abundance in Bolinao, northern Philippines. Mar Ecol Prog Ser 247: 183-195

Schories D, Selig U, Jegzentis K, Schubert H (2005) Klassifizierung der äußeren Küstengewässer an der deutschen Ostseeküste nach der Europäischen Wasserrahmenrichtlinie anhand von Makrophyten - eine Zwischenbilanz. Rostock Meeresbiol Beitr 14:135-150

Schories D, Pehlke C, Selig U (2009) Depth distributions of Fucus vesiculosus L. and Zostera marina L. as classification parameters for implementing the European Water Framework Directive on the German Baltic coast. Ecol Indic 9:670-680

Schramm W (1996) The Baltic Sea and its transition zones. In: Schramm W, Nienhuis PH (eds) Marine benthic vegetation. Recent changes and the effects of eutrophication. Springer-Verlag, Berlin, p 131-163

Schubert PR, Karez R, Reusch TBH, Dierking J (2013) Isotopic signatures of eelgrass (Zostera marina L.) as bioindicator of anthropogenic nutrient input in the western Baltic Sea. Mar Pollut Bull 72:64-70

Siegel H, Gerth M (2011) Development of sea surface temperature in the Baltic Sea in 2010. www.helcom.fi/ baltic-sea-trends/environment-fact-sheets/ (accessed on 14 May 2014)

Touchette BW, Burkholder JM (2000) Review of nitrogen and phosphorus metabolism in seagrasses. J Exp Mar Biol Ecol 250:133-167

Turner SJ, Hewitt JE, Wilkinson MR, Morrisey DJ, Thrush SF, Cummings VJ, Funnell G (1999) Seagrass patches and landscapes: the influence of wind-wave dynamics and hierarchical arrangements of spatial structure on macrofaunal seagrass communities. Estuaries 22:1016-1032

van Tussenbroek BI, Cortés J, Collin R, Fonseca AC and others (2014) Caribbean-wide, long-term study of seagrass beds reveals local variations, shifts in community structure and occasional collapse. PLoS ONE 9:e90600

Vaudrey JMP, Kremer JN, Branco BF, Short FT (2010) Eelgrass recovery after nutrient enrichment reversal. Aquat Bot 93:237-243

Waycott M, Duarte CM, Carruthers TJB, Orth RJ and others (2009) Accelerating loss of seagrasses across the globe threatens coastal ecosystems. Proc Natl Acad Sci USA 106:12377-12381

WFD (Water Framework Directive) (2000) Directive 2000/ 60/EC of the European Parliament and of the Council of 23 October 2000 establishing a framework for community action in the field of water policy. Off J Eur Communities L 327

- Williams SL (2007) Introduced species in seagrass ecosystems: status and concerns. J Exp Mar Biol Ecol 350: 89-110

Wiltshire KH, Malzahn A, Greve W, Wirtz K and others (2008) Resilience of North Sea phytoplankton spring blooms dynamics: an analysis of long-term data at Helgoland Roads. Limnol Oceanogr 53:1294-1302

> Wium-Andersen S, Borum J (1984) Biomass variation and autotrophic production of an epiphyte-macrophyte community in a coastal Danish area: I. Eelgrass (Zostera marina L.) biomass and net production. Ophelia 23: $33-46$

> Worm B, Reusch TBH (2000) Do nutrient availability and plant density limit seagrass colonization in the Baltic Sea? Mar Ecol Prog Ser 200:159-166

- Wright JP, Jones CG (2006) The concept of organisms as ecosystem engineers ten years on: progress, limitations, and challenges. Bioscience 56:203-209

Submitted: July 11, 2014; Accepted: November 25, 2014 Proofs received from author(s): February 16, 2015
Editorial responsibility: Kenneth Heck Jr., Dauphin Island, Alabama, USA 